\title{
Faktor yang Memengaruhi Kesalahan Persepsi Ibu tentang Status Gizi Anak
}

\section{Predictors of Maternal Misclassification of Child's Weight Status}

\author{
Arfianti $^{1^{*}}$, Tri Muhti Puja Kesuma², Muhammad Beni Septima ${ }^{2}$, Riefni Silara Dini², \\ Fifia Chandra ${ }^{3}$ \\ ${ }^{1}$ Bagian Biologi Kedokteran Fakultas Kedokteran Universitas Riau, Pekanbaru \\ ${ }^{2}$ Fakultas Kedokteran Universitas Riau, Pekanbaru \\ ${ }^{3}$ Bagian Ilmu Kesehatan Masyarakat Fakultas Kedokteran Universitas Riau, Pekanbaru \\ (*arfianti@unri.ac.id)
}

\begin{abstract}
ABSTRAK
Gangguan gizi merupakan masalah kesehatan yang serius pada anak di Indonesia. Ibu memainkan peranan yang penting dalam pencegahan gangguan gizi pada anak. Tujuan penelitian ini adalah membandingkan status gizi anak sekolah dasar berdasarkan penilaian ibu dan pengukuran antropometri serta menganalisis faktor-faktor yang memengaruhi kesalahan persepsi ibu tentang status gizi anak. Jenis penelitian adalah observasional analitik dengan desain cross-sectional. Sampel penelitian meliputi $250 \mathrm{ibu}$ dari anak kelas 4 dan 5 di 6 (enam) sekolah dasar negeri di Kota Pekanbaru yang diperoleh dengan metode proportional quota sampling. Status gizi anak dikategorikan berdasarkan baku antropometri World Health Organization (WHO) 2006. Persepsi ibu tentang status gizi anak diukur menggunakan kuesioner. Berdasarkan pengukuran antropometri didapatkan $28 \%$ anak dengan status gizi lebih dan 10\% anak dengan status gizi kurang, sedangkan bedasarkan persepsi ibu terdapat 4,8\% anak dengan status gizi lebih dan 12,8\% anak dengan status gizi kurang. Sebanyak 34,8\% ibu salah dalam menilai status gizi anak dan kesesuaian terhadap pemeriksaan antropometri tergolong buruk (koefisien Kappa 0,02). Ibu yang bekerja lebih cenderung salah dalam menilai status gizi anak dibanding ibu yang tidak bekerja $(p=0,004)$.
\end{abstract}

Kata kunci : Antropometri, pekerjaan, penilaian ibu, status gizi

\section{ABSTRACT}

Malnutrition is a significant health problem among Indonesian children. Mothers play a very important role in the prevention of childhood malnutrition. This study aimed to compare the child's nutritional status based on mothers' perception and anthropometry measurement and to analyze contributing factors of maternal misclassification of a child's weight status. This was an analytical observational study with a cross-sectional design. Research subjects included 250 mothers of grade 4 and 5 students from 6 elementary schools in Pekanbaru city recruited by the proportional quota sampling method. The Nutritional status of children was classified according to the 2006 World Health Organization (WHO) anthropometry standard. Mothers' perception of child's weight status was collected using questionnaires. Based on anthropometry measurement, $28 \%$ and $10 \%$ of children were overweight and underweight, respectively. In contrast, according to mothers, 4,8\% of children were overweight and $12,8 \%$ ofchildren were underweight. As many as $34.8 \%$ of mothers had incorrect perceptions about the nutritional status of their children and there was a poor agreement of mothers 'perception and child's nutritional status (Kappa coefficient of 0,02). Working mothers were more likely to underestimate their child's weight status compared to stay-at-home mothers ( $p=0,004)$.

Keywords : Anthropometry, working status, mothers' perception, nutritional status 


\section{PENDAHULUAN}

Gangguan gizi baik berupa gizi lebih maupun gizi kurang merupakan masalah kesehatan yang penting di seluruh dunia terutama di negara-negara berkembang seperti Indonesia. Berdasarkan Riset Kesehatan Dasar (Riskesdas) tahun 2018, proporsi anak balita dengan gizi kurang dan gizi buruk masih cukup tinggi yaitu $17,7 \%$, meskipun angka ini mengalami penurunan dibanding data tahun 2013 yaitu sebesar 19,6\%. Pada waktu yang bersamaan, angka kejadian gizi lebih pada anak umur 5-12 tahun mengalami peningkatan dari $19,6 \%$ pada tahun 2013 menjadi $20 \%$ pada tahun 2018. ${ }^{1,2}$ Kondisi malnutrisi lain yang cukup memprihatinkan adalah 30,8\% anak Indonesia mengalami tinggi badan yang relatif pendek dibanding tinggi badan anak seusianya (stunting). ${ }^{1}$ Data ini mengindikasikan bahwa Indonesia sedang mengalami triple burden of malnutrition .

Status gizi dipengaruhi oleh banyak faktor antara lain faktor genetik, pola makan, aktivitas fisik, perilaku sedentary serta status demografi orangtua seperti usia, jenis kelamin, pekerjaan, pendapatan dan pendidikan. ${ }^{3,4}$ Lingkungan seperti keluarga, teman, dan media merupakan pihak yang berperan dalam membentuk pola hidup yang tidak sehat seperti diet tinggi kalori, perilaku sedentary dan kurangnya aktivitas fisik pada anak. Orangtua, terutama ibu, memainkan peranan yang sangat penting dalam mencegah gangguan gizi pada anak karena ibu mempunyai interaksi yang lebih sering dengan anak dibanding ayah. ${ }^{5-7}$ Kemampuan seorang ibu dalam mengenali gangguan gizi pada anak merupakan keterampilan yang sangat penting dalam perannya sebagai role model (panutan) dalam membentuk kebiasaan hidup sehat pada anak. ${ }^{8}$ Beberapa penelitian terdahulu yang diadakan di negara-negara maju menunjukkan rendah-nya kemampuan ibu dalam menilai status gizi anak yang ditunjukkan dengan persepsi yang salah tentang status gizi anak jika dibandingkan dengan hasil pengukuran objektif dari status gizi. Suatu penelitian yang meliputi beberapa kota di Inggris terhadap 2976 anak berusia 10-11 tahun menunjukkan lebih kurang 30\% orangtua mempunyai persepsi yang salah tentang status gizi anaknya. ${ }^{9}$ Hasil yang hampir sama juga dilaporkan pada satu penelitian di Brasil dimana $45 \%$ orang tua menganggap anaknya memiliki status gizi normal meskipun pemeriksaan antropometri menunjukkan anak termasuk dalam gizi lebih (under estimation). ${ }^{10}$ Selain itu juga dilaporkan bahwa usia, pekerjaan, pendidikan, status perkawinan dan penghasilan keluarga memengaruhi penilaian orang tua tentang status gizi anak. ${ }^{11,12}$ Meskipun gangguan gizi pada anak telah banyak diteliti di Indonesia namun penelitian faktor-faktor yang memengaruhi kesalahan persepsi ibu tentang status gizi anak belum pernah dilakukan. Penelitian ini sangat penting dilakukan oleh karena penanganan gangguan gizi pada anak memerlukan partisipasi aktif dari keluarga khususnya ibu. Kesadaran ibu tentang masalah gizi yang dialami anaknya merupakan satu langkah penting dalam tata laksana gangguan gizi pada anak. Berdasarkan latar belakang diatas, penelitian ini bertujuan untuk mengetahui persepsi ibu tentang status status gizi anak sekolah dasar untuk selanjutnya dibandingkan dengan hasil pemeriksaan antropometri untuk menilai ketepatan persepsi ibu.

\section{BAHAN DAN METODE}

Jenis penelitian adalah observasional analitik dengan desain cross-sectional. Penelitian ini dilaksanakan di 6 (enam) SDN di Kota Pekanbaru yang dipilih untuk dapat mewakili beberapa kecamatan yang ada di Kota Pekanbaru. Penelitian berlangsung pada bulan Maret-Agustus 2018. Populasi pada penelitian ini adalah ibu dan siswa/i sekolah dasar kelas 4 dan 5 yang berjumlah 250 orang. Penelitian ini hanya mengikutsertakan siswa/i kelas 4 dan 5 dengan pertimbangan kemampuan mereka untuk memahami dan menjawab pertanyaan yang ada di kuesioner sudah lebih baik dibanding anak kelas 1-3. Sementara itu, siswa/i kelas 6 tidak dilibatkan dengan pertimbangan aktivitas penelitian berpotensi mengganggu konsentrasi mereka dalam menghadapi ujian nasional. Sampel adalah bagian dari populasi yang memenuhi kriteria inklusi dan diperoleh dengan mengunakan metode proportional quota sampling yaitu pemilihan sampel yang proportional berdasarkan karakteristik populasi (total jumlah siswa di setiap sekolah, kelas, dan jenis kelamin). ${ }^{13}$ Penentuan jumlah sampel minimal yang diambil berdasarkan perhitungan rumus cross-sectional (estimasi proporsi) yaitu sebanyak 96 sampel. ${ }^{14}$ Kriteria inklusi yaitu ibu dari siswa/i kelas 4 dan 5 yang dapat membaca dan menulis 
dan bersedia menjadi responden dalam penelitian sedangkan kriteria eksklusi yaitu data yang tidak lengkap. Variabel bebas dalam penelitian ini adalah umur, pendidikan dan pekerjaan ibu serta penghasilan keluarga, jumlah anak dan status gizi ibu. Variabel terikat dalam penelitian ini adalah persepsi ibu tentang status gizi anak. Penelitian ini telah lolos kaji etik oleh Komisi Etik Penelitian Kedokteran dan Kesehatan Fakultas Kedokteran Universitas Riau.

Penilaian status gizi dilakukan menggunakan Indeks Massa Tubuh (IMT) yang merupakan berat badan (dalam kilogram) dibagi dengan kuadrat tinggi badan (dalam meter). Alat yang digunakan untuk mengukur berat badan anak adalah timbangan injak kapasitas $130 \mathrm{~kg}$ dengan ketelitian $0,1 \mathrm{~kg}$ dan tinggi badan anak mengunakan alat microtoise kapasitas $200 \mathrm{~cm}$ dengan ketelitian $0,1 \mathrm{~cm}$. Status gizi anak diklasifikasikan menurut baku antropometri WHO 2006 untuk anak umur 5-18 tahun sesuai usia dan jenis kelamin menggunakan WHO Anthroplus software version 1.04. Status gizi anak digolongkan menjadi gizi kurang (kombinasi kurus dan sangat kurus), normal dan obesitas (kombinasi gemuk dan obesitas) oleh karena cukup sulit bagi ibu untuk membedakan antara kurus dan sangat kurus serta antara gemuk dan obesitas. Persepsi ibu tentang status gizi anak diukur menggunakan kuesioner melalui pertanyaan sederhana: "Dibanding anak lain yang sebaya, anak saya termasuk?" Orang tua memilih jawaban dari tiga pilihan yaitu kurus, normal atau obesitas. ${ }^{10,15}$ Penentuan status gizi ibu diukur berdasarkan BB dan TB yang dilaporkan oleh ibu melalui pengisian kuesioner (self-reported). Status gizi ibu diklasifikasikan berdasarkan IMT menurut kriteria Asia-Pasifik menjadi obesitas (kombinasi gemuk dan obesitas) dan bukan obesitas (kombinasi kurus, sangat kurus dan normal). Perbedaan status gizi anak berdasarkan persepsi ibu dan pengukuran antropometri dikategorikan sebagai: 1) Underestimation (penilaian status gizi anak yang diberikan oleh ibu lebih rendah dibandingkan hasil pengukuran antropometri); 2) Correct estimation (penilaian status gizi anak yang diberikan oleh ibu sama dengan hasil pengukuran antropometri), 3) Overestimation (penilaian status gizi anak yang diberikan oleh ibu lebih tinggi dibandingkan dengan hasil pengukuran antropometri. ${ }^{15}$ Pendidikan ibu dikelompokkan menjadi pendidikan rendah (tidak tamat SMA/sederajat) dan tinggi (tamat SMA/sederajat). Penghasilan keluarga digolongkan menjadi rendah (Upah Minimum Kabupaten/Kota $[\mathrm{UMK}] \leq 2.557 .486,73 /$ bulan) dan tinggi (UMK $>2.557 .486,73 /$ bulan). ${ }^{16}$

Analisis univariat dilakukan terhadap seluruh variabel penelitian untuk menyajikan data secara deskriptif dalam bentuk tabel distribusi frekuensi atau diagram batang. Koefisien Kappa digunakan untuk menguji kesesuaian status gizi berdasarkan penilaian orang tua dan pengukuran antropometri. Nilai Kappa $<0.8$ merupakan indikasi bahwa persepsi ibu buruk sedangkan nilai $\geq 0.8$ merupakan indikasi bahwa persepsi ibu baik. ${ }^{10} \mathrm{Un}$ tuk menentukan faktor-faktor yang mempengaruhi ketepatan persepsi ibu tentang status gizi anak dilakukan analisis bivariat menggunakan uji Chisquare. Selanjutnya analisis multivariat dilakukan untuk mengetahui faktor yang paling dominan memengaruhi penilaian ibu menggunakan uji $b i$ nary logistic regression terhadap variabel dengan nilai $p<0,25$ pada analisis bivariat. Pada analisis multivariat, overestimation dan underestimation dikelompokkan menjadi kelompok persepsi "tidak sesuai" sedangkan correct estimation merupakan kelompok persepsi "sesuai". Uji statistik dianggap bermakna jika $p<0,05$.

\section{HASIL}

Profil sosiodemografi dan status gizi ibu dapat dilihat pada Tabel 1. Sebagian besar ibu berusia $>30$ tahun, pendidikan tamat SMA/sederajat, merupakan ibu bekerja dan memiliki anak $>2$ orang. Frekuensi ibu dengan penghasilan rendah tidak jauh berbeda dengan ibu dengan penghasilan tinggi. Sebanyak $35,6 \%$ ibu tergolong ke dalam obesitas.

Distribusistatusgizianakberdasarkan pengukuran antropometri dan persepsi ibu dapat dilihat pada Gambar 1. Proporsi anak dengan gizi kurang tidak jauh berbeda berdasarkan pengukuran antropometri dan persepsi ibu. Namun perbedaan yang cukup besar ditemukan pada gizi normal dan gizi lebih. Proporsi anak dengan obesitas berdasarkan persepsi ibu jauh lebih rendah dibandingkan hasil pengukuran antropometri $(4,8 \%$ vs $28 \%)$.

Secara keseluruhan sebanyak $65,2 \%$ ibu dengan tepat menilai status gizi anak, namun 
Tabel 1. Karakteristik Sosiodemografi dan Status Gizi Ibu

\begin{tabular}{lcc}
\hline \multicolumn{1}{c}{ Variabel } & $\mathbf{n}$ & $\mathbf{\%}$ \\
\hline $\begin{array}{l}\text { Umur } \\
\leq 30 \text { tahun } \\
\quad 30 \text { tahun }\end{array}$ & 5 & 2 \\
$\begin{array}{l}\text { Pendidikan } \\
\quad \text { Rendah } \\
\quad \text { Tinggi }\end{array}$ & 245 & 98 \\
Pekerjaan & & \\
$\quad$ Bekerja & 66 & 26,4 \\
$\quad$ Tidak bekerja & 184 & 73,6 \\
Penghasilan Keluarga & 178 & 71,2 \\
$\quad$ Tinggi & 72 & 28,8 \\
$\quad$ Rendah & 133 & 53,2 \\
Jumlah Anak & 117 & 46,8 \\
$\quad>2$ anak & & \\
$\quad \leq 2$ anak & 167 & 66,8 \\
Status Gizi Ibu & 83 & 33,2 \\
$\quad$ Obesitas & & \\
$\quad$ Tidak obesitas & 89 & 35,6 \\
\end{tabular}

Sumber: Data Primer, 2018

$34,8 \%$ ibu salah dalam menentukan status gizi anak. Gambar 2 memperlihatkan kesesuaian persepsi ibu tentang status gizi anak dibandingkan dengan pengukuran antropometri. Pada kelompok anak yang mengalami gizi kurang, 40\% ibu menganggap anaknya memiliki status gizi normal (overestimation), sedangkan pada anak gizi normal, 9,7\% ibu mengatakan anaknya mengalami gizi kurang (underestimation) dan 1,3\% ibu menilai anak termasuk dalam gizi lebih (overestimation). Sebaliknya pada kelompok anak dengan gangguan gizi lebih, sebanyak $85,7 \%$ ibu menilai status gizi anaknya masih dalam batas normal (underestimation). Kesesuaian antara status gizi anak berdasarkan persepsi ibu dan pengukuran antropometri memperlihatkan nilai koefisien Kappa 0,02 yang menunjukkan bahwa persepsi ibu terhadap status gizi anak tergolong buruk.

Hasil analisis bivariat pada penelitian ini menunjukkan pekerjaan, penghasilan dan antropometri mempengaruhi ketepatan persepsi ibu tentang status gizi anak (Tabel 2). Ibu yang bekerja mempunyai risiko 1,9 kali lebih tinggi untuk salah dalam mengenali status gizi anaknya dibanding ibu yang tidak bekerja $(p=0,000)$. Selanjutnya ibu dari keluarga dengan penghasilan tinggi 1,6 lebih sering salah dalam menilai status gizi anak

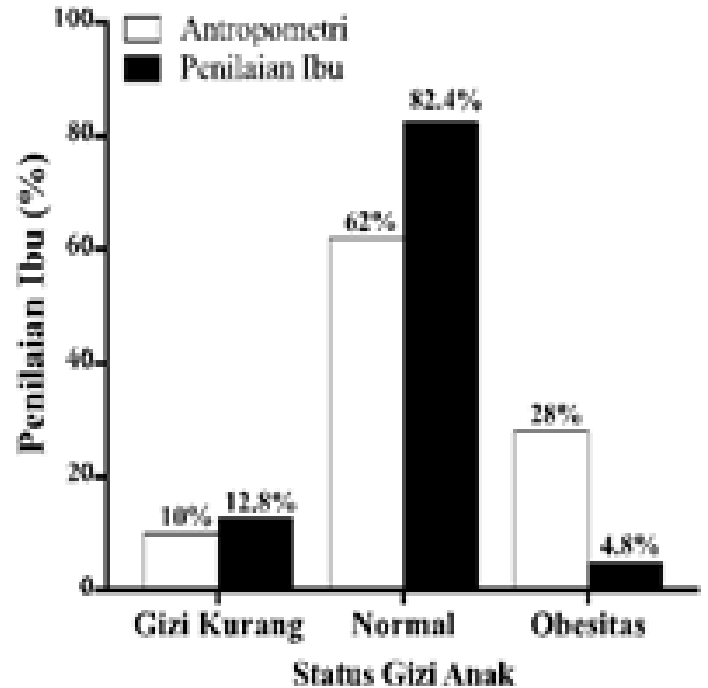

\section{Gambar 1. Status Gizi Berdasarkan Pengukuran Antropometri dan Penilaian Ibu}

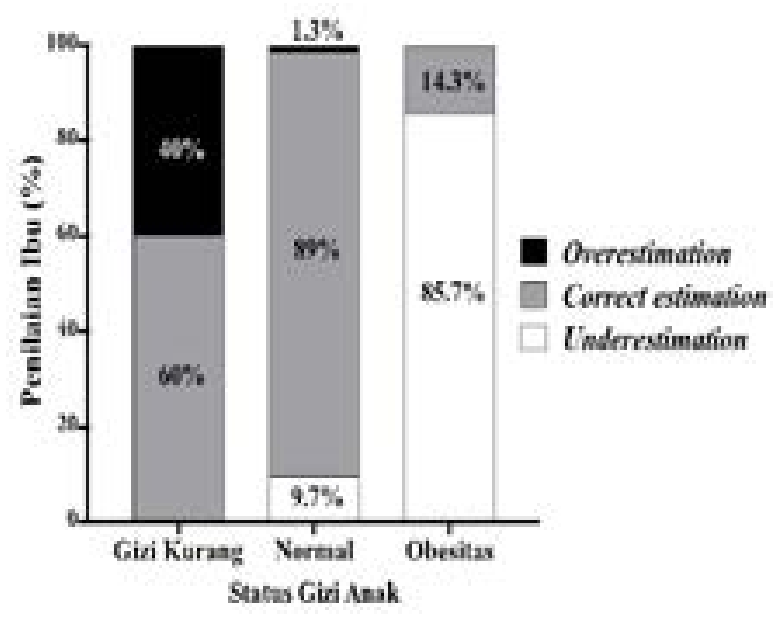

\section{Gambar 2. Kesesuaian Penilaian Ibu tentang} Status Gizi

dibandingkan dengan keluarga dengan penghasilan rendah $(p=0,007)$. Berdasarkan status gizi, ibu obes 1,4 lebih sering salah dalam menilai status gizi anak dibanding ibu dengan yang tidak obes $(p=0,037)$. Selanjutnya analisis multivariat dilakukan pada variabel pendidikan, pekerjaan, penghasilan keluarga dan status gizi ibu (Tabel 3) yang menunjukkan pekerjaan ibu merupakan satu-satunya varibel yang memengaruhi persepsi ibu tentang status gizi anak $(p=0,004)$.

\section{PEMBAHASAN}

Pemeriksaan antropometri pada penelitian 
Tabel 2. Hasil Analisis Bivariat Sosiodemografi dan Antropometri Ibu dengan Kesesuaian Penilaian Status Gizi Anak

\begin{tabular}{|c|c|c|c|c|c|c|c|}
\hline \multirow{3}{*}{ Variabel } & \multicolumn{4}{|c|}{ Kesesuaian penilaian } & \multirow{3}{*}{$\mathbf{p}$} & \multirow{3}{*}{ PR } & \multirow{3}{*}{$95 \%$ CI } \\
\hline & \multicolumn{2}{|c|}{$\begin{array}{c}\text { Tidak sesuai } \\
(\mathrm{n}=87)\end{array}$} & \multicolumn{2}{|c|}{ Sesuai $(n=163)$} & & & \\
\hline & $\mathrm{n}$ & $\%$ & $\mathbf{n}$ & $\%$ & & & \\
\hline \multicolumn{8}{|l|}{ Umur } \\
\hline$\leq 30$ tahun & 2 & 40 & 3 & 60 & 1,000 & $1,14 \mathrm{ref}$ & $0,13-4,86$ \\
\hline$>30$ tahun & 85 & 34,7 & 160 & 65,3 & & & \\
\hline \multicolumn{8}{|l|}{ Pendidikan } \\
\hline Rendah & 16 & 24,2 & 50 & 75,8 & 0,051 & 0,62 ref & $1,03-3,71$ \\
\hline Tinggi & 71 & 38,6 & 113 & 61,4 & & & \\
\hline \multicolumn{8}{|l|}{ Pekerjaan } \\
\hline Bekerja & 38 & 52,8 & 34 & 47,2 & 0,000 & $1,91 \mathrm{ref}$ & $1,66-5,19$ \\
\hline Tidak bekerja & 49 & 27,5 & 129 & 72,5 & & & \\
\hline \multicolumn{8}{|c|}{ Penghasilan keluarga } \\
\hline Tinggi & 57 & 42,9 & 76 & 57,1 & 0,007 & $1,67 \mathrm{ref}$ & $1,26-3,72$ \\
\hline Rendah & 30 & 25,6 & 87 & 74,4 & & & \\
\hline \multicolumn{8}{|l|}{ Jumlah Anak } \\
\hline$>2$ anak & 60 & 35,9 & 107 & 64,1 & 0,696 & $1,10 \mathrm{ref}$ & $0,66-2,03$ \\
\hline$\leq 2$ anak & 27 & 32,5 & 56 & 67,5 & & & \\
\hline \multicolumn{8}{|l|}{ Status gizi ibu } \\
\hline Obesitas & 39 & 43,8 & 50 & 56,2 & 0,037 & $1,46 \mathrm{ref}$ & $0,31-0,93$ \\
\hline Tidak Obeitas & 48 & 29,8 & 113 & 70,2 & & & \\
\hline
\end{tabular}

Sumber: Data Primer, 2018

Keterangan : $\mathrm{PR}=$ Prevalence Ratio $; \mathrm{CI}=$ Confidence Interval

Tabel 3. Hasil Analisis Multivariat Variabel yang Mempengaruhi KesesuaianPenilaian Ibu

\begin{tabular}{|c|c|c|c|c|c|c|}
\hline \multirow{3}{*}{ Karakteristik Ibu } & \multicolumn{4}{|c|}{ Kesesuaian penilaian } & \multirow{3}{*}{$\mathbf{p}$} & \multirow{3}{*}{$95 \% \mathrm{CI}$} \\
\hline & \multicolumn{2}{|c|}{ Tidak sesuai $(\mathrm{n}=87)$} & \multirow{2}{*}{$\begin{array}{c}\text { Sesuai } \\
n \\
\end{array}$} & \multirow{2}{*}{$\begin{array}{c}(n=163) \\
\%\end{array}$} & & \\
\hline & $\mathbf{n}$ & $\%$ & & & & \\
\hline Pendidikan & 16 & 24,2 & 50 & 75,8 & 0,963 & $0,45-2,10$ \\
\hline Rendah & 71 & 38,6 & 113 & 61,4 & & \\
\hline \multicolumn{7}{|l|}{ Tinggi } \\
\hline Pekerjaan & 38 & 52,8 & 34 & 47,2 & 0,004 & $0,20-0,74$ \\
\hline Bekerja & 49 & 27,5 & 129 & 72,5 & & \\
\hline \multicolumn{7}{|l|}{ Tidak bekerja } \\
\hline Penghasilan keluarga & 57 & 42,9 & 76 & 57,1 & 0,092 & $0,32-1,08$ \\
\hline Tinggi & 30 & 25,6 & 87 & 74,4 & & \\
\hline \multicolumn{7}{|l|}{ Rendah } \\
\hline Status gizi ibu & 39 & 43,8 & 50 & 56,2 & 0,075 & $0,94-2,92$ \\
\hline Obesitas & 48 & 29,8 & 113 & 70,2 & & \\
\hline Tidak Obeitas & & & & & & \\
\hline
\end{tabular}

Sumber: Data Primer, 2018

ini menunjukkan $28 \%$ anak termasuk mengalami gizi lebih (overweight/obesitas), 10\% gizi kurus, dan $62 \%$ gizi normal. Prevalensi gizi lebih pada penelitian ini sedikit lebih tinggi dibandingkan prevelensi gizi lebih pada anak usia 5-12 tahun yang dilaporkan oleh Riskesdas 2018 yaitu sebesar $20 \% .{ }^{17}$ Hasil penelitian ini sejalan dengan penelitian yang dilaporkan di sekolah dasar di Kota Surakarta $^{18}$ dan Kota Depok. ${ }^{19}$ Demikian pula penelitian terhadap anak kelas 3, 4, dan 5 seko- 
lah dasar di Bantul Yogyakarta yang menunjukkan terdapat $16 \%$ anak mengalami obesitas dan $13,2 \%$ anak mengalami overweight. ${ }^{20}$ Kondisi ini mengindikasikan peningkatan gizi lebih pada anak usia sekolah dasar merupakan permasalahan nasional dan menunjukkan tren peningkatan angka kejadian yang cukup pesat. Adanya peningkatan prevalensi gizi lebih pada anak ini sangat mengkhawatirkan karena kondisi gizi lebih pada masa anak-anak akan meningkatkan risiko obesitas pada saat dewasa. Selain itu obesitas juga meningkatkan risiko penyakit-penyakit seperti hipertensi, aterosklerosis, abnormalitas kadar lipid darah (dislipidemia), dan sindrom metabolik. ${ }^{3,21}$ Peningkatan prevalensi obesitas pada anak juga diprediksi akan berdampak pada penurunan produktivitas kerja pada saat mereka dewasa dan berpotensi menyebabkan kerugian ekonomi sebesar 0,003\%-0,004\% dari total Produk Domestik Bruto (PDB) nasional. ${ }^{22}$

Penelitian ini juga memperlihatkan ketidaksesuaian distribusi status gizi anak berdasarkan pengukuran antropometri dan persepsi ibu. Meskipun hasil pemeriksaan antropometri menunjukkan $28 \%$ anak termasuk mengalami gizi lebih, hanya $4,8 \%$ ibu yang dapat mengenali masalah gizi lebih pada anaknya. Sebaliknya proporsi anak dengan status gizi normal lebih tinggi berdasarkan penilaian ibu dibanding pengukuran antropometri $(82,4 \%$ vs $62 \%)$. Data ini mengindikasikan rendahnya kemampuan ibu dalam menilai status gizi anak. Secara keseluruhan, ibu mempunyai persepsi yang salah dalam menilai status gizi anak dan analisis lebih lanjut memperlihatkan ibu lebih cenderung tidak mampu menilai status gizi anak ketika anaknya mengalami overweight/obesitas dibanding jika anaknya menderita gizi kurang $(40 \%)$. Hasil penelitian ini sejalan dengan penelitian yang dilaporkan di Brazil dimana sebanyak $48 \%$ ibu tidak mampu menilai status gizi anak dengan tepat. ${ }^{10}$ Demikian pula penelitian yang dilakukan di Austria pada ibu-ibu dari anak ber-usia 0-14 tahun, sebanyak $63,2 \%$ mengatakan status gizi anaknya masih dalam batas normal meskipun pada kenyataannya anak termasuk obesitas berdasarkan pengukuran antropometri. ${ }^{10}$ Penelitian ini juga menunjukkan ibu lebih sering salah dalam menentukan status gizi anak jika anaknya mengalami obesitas dibanding jika anaknya menga- lami underweight atau dengan kata lain ibu lebih cenderung untuk underestimate diban-ding overestimate dalam menilai status gizi anak. ${ }^{10}$

Beberapa faktor diduga memengaruhi kemampuan penilaian ibu tentang status gizi anak. Penelitian ini didapatkan hasil bahwa ibu yang bekerja lebih sering salah dalam menentukan status gizi anak dibandingkan ibu yang tidak bekerja. Hal ini sesuai dengan penelitian terbaru pada 20.000 keluarga di Inggris yang melaporkan hubungan antara ibu bekerja dengan kejadian obesitas pada anak usia sekolah. ${ }^{23}$ Anak dari ibu bekerja mempunyai risiko $25 \%$ lebih besar untuk mengalami overweight dibanding ibu yang tidak bekerja. Faktor-faktor yang memengaruhi kejadian gizi lebih ini diantaranya anak dari ibu bekerja lebih sering melewatkan sarapan dan menghabiskan waktu menonton TV lebih dari 3 jam sehari sehingga penelitian ini menyimpulkan ibu yang bekerja meningkatkan aktivitas sedentary dan pola makan yang tidak sehat. Selain itu Farahani, dkk melaporkan bahwa ibu yang memiliki banyak jam kerja lebih berisiko mempunyai anak yang obesitas. ${ }^{15}$ Hal ini disebabkan karena ibu yang bekerja relatif menghabiskan waktu yang lebih sedikit dengan anak dibandingkan dengan ibu yang tidak bekerja. Selain itu, jika dianalisis secara terpisah, status gizi ibu dan penghasilan keluarga memiliki hubungan yang bermakna dengan kemampuan ibu dalam menilai status gizi anak. Ibu yang obes mempunyai kecenderungan 1,46 kali lebih sering salah dalam menilai status gizi anak dibanding ibu yang tidak obes. Hasil ini sesuai dengan penelitian terdahulu yang menunjukkan bahwa ibu yang overweight/obes lebih sering salah dalam menilai status gizi anak..$^{15,24}$ Ini mengindikasikan bahwa faktor genetik dan lingkungan yang membentuk perilaku anak merupakan faktor yang penting pada terjadinya gangguan gizi pada anak. Orang tua yang overweight/obes cenderung mempunyai perilaku dan kebiasaan yang meningkatkan risiko gizi lebih. Penelitian yang dilakukan di salah satu negara bagian di Ameriksa Serikat memperlihatkan anak dari keluarga yang obes lebih banyak mengkonsumsi makanan tinggi lemak dan menghabiskan waktu lebih lama di depan TV dibanding keluarga non-obes. ${ }^{25}$ Berkaitan dengan penghasilan keluarga, keluarga dengan penghasilan tinggi 1,67 kali lebih sering salah 
dalam menilai status gizi anak dibanding dengan keluarga dengan pendapatan rendah. Namun hasil yang berbeda dilaporkan oleh pada suatu penelitian di Irlandia yang menyatakan bahwa ibu dari keluarga yang berpenghasilan rendah lebih sering salah dalam menilai status gizi anaknya dibanding ibu dari keluarga dengan penghasilan tinggi. ${ }^{26} \mathrm{Hal}$ ini berkaitan dengan keengganan orang tua yang berpenghasilan rendah untuk mengakui bahwa anak mereka mengalami kelebihan berat badan. ${ }^{27}$ Perbedaan hasil ini kemungkinan dipengaruhi oleh perbedaan populasi penelitian, dimana budaya dan kepercayaan masyarakat setempat merupakan faktor penting dalam membentuk pola pikir seseorang. Meskipun demikian pada penelitian ini status gizi ibu dan penghasilan keluarga tidak memiliki hubungan yang bermakna dengan penilaian ibu setelah dilakukan analisis secara simultan terhadap seluruh variabel yang ada.

Sesuai dengan penelitian terdahulu, ${ }^{24}$ penelitian ini tidak menemukan adanya hubungan antara jumlah anak, umur dan pendidikan ibu dengan kemampuan ibu dalam menilai status gizi anak. Namun penelitian di Yunani menunjukkan ibu yang berpendidikan tinggi mempunyai kemampuan lebih baik dalam menilai status gizi anak dibandingkan dengan ibu yang berpendidikan rendah. ${ }^{28}$ Pendidikan memengaruhi mudah tidaknya ibu dalam menerima informasi kesehatan termasuk masalah gangguan gizi dan ibu dengan pendidikan yang tinggi pada umumnya lebih menyadari dampak gangguan gizi terhadap fisik, sosial dan emosional dari anak-anak. ${ }^{28}$ Namun di sisi lain, ibu yang berpendidikan tinggi pada umumnya merupakan ibu bekerja sehingga kemungkinan hal ini merupakan salah satu faktor perancu yang menyebabkan tidak ditemukannya hubungan antara pendidikan dan penilaian ibu. Pada penelitian ini juga tidak didapatkan hubungan antara jumlah anak dengan kesesuaian penilaian ibu. Jumlah anak berkaitan dengan dengan terjadinya gangguan gizi pada keluarga dengan pendapatan yang rendah. ${ }^{29}$ Keluarga dengan pendapatan yang rendah akan sulit memenuhi kebutuhan keluarganya terutama jika memiliki anggota keluarga yang banyak. Anak-anak yang tumbuh di dalam keluarga dengan pendapatan rendah merupakan kelompok paling rawan dalam masalah gizi kurang. ${ }^{29}$

Hal penting yang dapat diambil dari pene- litian ini adalah pentingnya peningkatan kemampuan orangtua terutama ibu dalam memantau status gizi anak sehingga ibu dapat lebih berperan dalam mendukung dan mempromosikan gaya hidup sehat. ${ }^{15}$ Fakta bahwa kebanyakan ibu salah menilai anak mereka yang obesitas sebagai anak dengan berat badan normal, mungkin mencerminkan ketidakinginan ibu untuk mengakui masalah gizi pada anak mereka ${ }^{30}$ atau disebabkan persepsi ibu bahwa obesitas pada anak itu wajar dan menganggap mereka akan kurus dengan sendirinya ketika beranjak dewasa. ${ }^{31}$ Selain itu, pada umumnya ibu cenderung lebih khawatir jika anaknya mengalami gizi kurang dibanding gizi lebih. Orangtua baru akan berkonsultasi dengan dokter ketika gangguan gizi telah berdampak pada kesehatan anak. Oleh karena itu seluruh tenaga kesehatan perlu meningkatkan aktivitas promosi kesehatan terutama terhadap ibu untuk meningkatkan kesaradaran mereka akan pentingnya mengenali gangguan gizi pada anak sedini mungkin. ${ }^{32}$ Hasil dari penelitian ini juga dapat digunakan untuk pengembangan upaya penanggulangan gangguan gizi melalui program intervensi keluarga yang merupakan salah satu program yang diusung oleh Kementerian Kesehatan Republik Indonesia.

\section{KESIMPULAN DAN SARAN}

Distribusi status gizi anak berbeda antara hasil pemeriksaan antropometri dan penilaian ibu dimana sebanyak $34,8 \%$ ibu tidak mampu menilai status gizi anak dengan benar. Ibu yang memiliki anak overweight/obesitas cenderung lebih sering salah dalam menilai status gizi anak dibanding ibu dari anak yang mengalami gizi kurang. Penelitian ini juga menunjukkan bahwa ibu yang bekerja merupakan kelompok yang paling rentan salah dalam menilai status gizi anak. Hasil penelitian ini mengindikasikan pentingnya untuk meningkatkan pengetahuan dan keterampilan orangtua (ibu) dalam menilai status gizi anak sebagai salah satu strategi penurunan angka kejadian gangguan gizi pada anak. Sehingga perlu dilakukan penelitian intervensi dengan fokus pada keluarga untuk melihat efektivitas pendidikan kesehatan terhadap kemampuan orangtua dalam mendeteksi anak dengan gangguan gizi. 


\section{DAFTAR PUSTAKA}

1. Kementerian Kesehatan Republik Indonesia. Riset Kesehatan Dasar 2013. Jakarta: Kementerian Kesehatan Republik Indonesia; 2013.

2. Kementerian Kesehatan Republik Indonesia. Riset Kesehatan Dasar 2010. Jakarta: Kementerian Kesehatan Republik Indonesia; 2010.

3. World Health Organization (WHO). Report of the Comission on Ending Childhood Obesity. Geneva: WHO; 2016.

4. Ijarotimi OS. Determinants of Childhood Malnutrition and Consequences in Developing Countries. Current Nutrition Reports. 2013;2(3):129-133.

5. Beets MW, Cardinal BJ, Alderman BL. Parental Social Support and the Physical Activity-Related Behaviors of Youth: A Review. Health Education Behavior. 2010;37(5):621644.

6. Østbye T, Malhotra R, Stroo M, Lovelady C, Brouwer R, Zucker N, et al. The Effect of the Home Environment on Physical Activity and Dietary Intake in Preschool Children. International Journal of Obesity. 2013;37(10):1314 1321.

7. Drenowatz C, Erkelenz N, Wartha O, Brandstetter S, Steinacker JM, on behalf of the URMEL-ICE Study Group. Parental Characteristics Have a Larger Effect on Children's Health Behaviour than Their Body Weight. Obesity Facts. 2014;7(6):388-398.

8. Parkinson KN, Reilly JJ, Basterfield L, Reilly JK, Janssen X, Jones AR, et al. Mothers' Perceptions of Child Weight Status and the Subsequent Weight Gain of their Children: A Population-Based Longitudinal Study. International Journal of Obesity. 2017;41(5):801806.

9. Black JA, Park M, Gregson J, Falconer CL, White B, Kessel AS, et al. Child Obesity CutOffs as Derived from Parental Perceptions: Cross-sectional Questionnaire. British Journal of General Practice. 2015;65(633):234239.

10. Warkentin S, Mais LA, Latorre MDR, Carnell S, Taddei JA. Factors Associated with Parental Underestimation of Child's Weight Status. Journal de Pediatria. 2018;94(2):162-169.

11. Shrewsbury V, Wardle J. Socioeconomic Sta- tus and Adiposity in Childhood: A Systematic Review of Cross-Sectional Studies 19902005. Obesity. 2008;16(2):275-284.

12. Dhayanaputri IS, Hartini TNS, Kristina SA. Persepsi Ibu, Guru dan Tenaga Kesehatan tentang Obesitas pada Anak Taman KanakKanak. Berita Kedokteran Masyarakat. 2011;27(1):32-40.

13. Sedgwick P. Proportional Quota Sampling. BMJ. 2012;345:6336.

14. Charan J, Biswas T. How to Calculate Sample Size for Different Study Designs in Medical Research? Indian Journal of Psychologic Medicine. 2013;35(2):121-126.

15. Farahani SJ, Chin YS, Taib MNM, Amiri P. Parental Correlates of Body Weight Status Among High School Students in Tehran. International Journal of Endocrinology \& Metabolism. 2017;15(2):15-17.

16. Badan Pusat Statistik. Peraturan Kepala Badan Pusat Statistik Nomor 37 Tahun 2010. Klasifikasi Perkotaan dan Perdesaan di Indonesia. Jakarta: Badan Pusat Statistik; 2010.

17. Kementerian Kesehatan Republik Indonesia. Riset Kesehatan Dasar 2018. Jakarta: Kementerian Kesehatan Republik Indonesia; 2013.

18. Rahmawati, Tuti MD. Gambaran Status Gizi pada Anak Sekolah Dasar. Profesi. 2016;14(1):72-76.

19. Amany T, Sekartini R. Hubungan Antara Status Gizi dengan Prestasi Belajar Siswa SDN 03 Pondok Cina Depok Tahun 2015. Sari Pediatri. 2017;18(6):487-491.

20. Zamzani M, Hadi H, Astiti D. Aktivitas Fisik Berhubungan dengan Kejadian Obesitas pada Anak Sekolah Dasar. Jurnal Gizi dan Dietetik Indonesia. 2016;4(3):123-128.

21. Sahoo K, Sahoo B, Choudhury AK, Sofi NY, Kumar R, Bhadoria AS. Childhood Obesity: Causes and Consequences. Journal of Family Medicine and Primary Care. 2015;4(2):187192.

22. Renyoet BS, Martianto D, Iskandar D. Estimasi Potensi Kerugian Ekonomi pada Balita Obesitas yang Diprediksi Mengalami Obesitas saat Dewasa di Indonesia. Media Kesehatan Masyarakat Indonesia. 2017;13(1):42-50.

23. Fitzsimons E, Pongiglione B. The Impact of Maternal Employment on Children's Weight: 
Evidence from the UK. SSM-Population Health. 2019;7:100333.

24. Nemecek D, Sebelefsky C, Woditschka A, Voitl P. Overweight in Children and Its Perception by Parents: Cross-sectional Observation in A General Pediatric Outpatient Clinic. BMC Pediatrics. 2017;17(212):1-10.

25. Davison KK, Francis LA, Birch LL. Reexamining Obesigenic Families: Parents' Obesity-Related Behaviors Predict Girls' Change in BMI. Obesity Research. 2005;13(11):19801990.

26. Hudson E, McGloin A, McConnon A. Parental Weight (Mis) Perceptions: Factors Influencing Parents' Ability to Correctly Categorise Their Child's Weight Status. Maternal and Child Health Journal. 2012;16(9):1801-1809.

27. Jain A, Sherman SN, Chamberlin LA, Carter Y, Powers SW, Whitaker RC. Why Don't Low-Income Mothers Worry About Their Preschoolers Being Overweight?. Pediatrics. 2001;107(5):1138-1146.

28. Manios Y, Kondaki K, Kourlaba G, Vasilo- poulou E, Grammatikaki E. Maternal Perceptions of Their Child's Weight Status: the GENESIS Study. Public Health Nutrition. 2009;12(8):1099-1105.

29. Ariesthi KD, Adhi KT, Wirawan DN. Faktor Risiko Gizi Buruk dan Gizi Kurang pada Balita di Kabupaten Sumba Barat Daya Nusa Tenggara Timur. Public Health and Preventive Medicine Archive. 2015;3(1):27-33.

30. Maynard LM, Galuska DA, Blanck HM, Serdula MK. Maternal Perceptions of Weight Status of Children. Pediatrics. 2003;111(5):1226-1231.

31. Leonita E, Nopriadi. Persepsi Ibu terhadap Obesitas pada Anak Sekolah Dasar. Jurnal Kesehatan Komunitas. 2010;1(1):39-48.

32. McDonald SW, Ginez HK, Vinturache AE, Tough SC. Maternal Perceptions of Underweight and Overweight for 6-8 Years Olds from A Canadian Cohort: Reporting Weights, Concerns and Conversations with Healthcare Providers. BMJ Open. 2016;6(10):1-7. 